\title{
Improvement of Sporulation Conditions of a New Strain of Bacillus amyloliquefaciens in Liquid Fermentation
}

\author{
Andrés Díaz-García*, Jennifer García-Riaño, Jimmy Zapata-Narvaez \\ Biological Control Laboratory, Tibaitatá Research Center, Colombian Corporation for Agricultural Research \\ (Corpoica), Bogotá, Colombia \\ Email: $\underline{\text { adiaz@corpoica.org.co, igarciar@corpoica.org.co, jzapatan@corpoica.org.co }}$
}

Received 20 March 2015; accepted 19 April 2015; published 21 April 2015

Copyright (C) 2015 by authors and Scientific Research Publishing Inc.

This work is licensed under the Creative Commons Attribution International License (CC BY). http://creativecommons.org/licenses/by/4.0/

(c) (i) Open Access

\begin{abstract}
The desirable active ingredients for the development of bioproducts based in Bacillus sp. for the control of soil pathogens are the spores because these structures exhibit more resistance and stability to conditions present during the fermentation, formulation, and storage processes. To improve the sporulation of a native strain of Bacillus amyloliquefaciens (Bs006) using liquid fermentation, some modifications in the concentrations of the components in a previously standardized culture media were made. Subsequently, five sporulation inducers (iron nitrate, mixture of salts, peroxide hydrogen, temperature, and initial cell concentration) were evaluated. The treatment with a mixture of salts in combination with an initial cell concentration of $1 \times 10^{8} \mathrm{cells} / \mathrm{ml}$ was selected because a final spore concentration of $1.05 \times 10^{10}$ spores $/ \mathrm{ml}$ after 66 hours with a fully substrate consumption and sporulation efficiency of $88.7 \%$ was obtained. To demonstrate the biological activity of $B$. amyloliquefaciens Bs006 in Cape gooseberry seedlings, a greenhouse bioassay was conducted, and statistical differences in plant growth-promoting parameters compared with previous media were not found. Additionally, the proposed modified media (coded as JM) presented a benefit-cost ratio 2.65 times higher compared with the baseline media.
\end{abstract}

\section{Keywords}

Bacillus amyloliquefaciens, Sporulation Induction, Liquid Media Design, Cape Gooseberry, Plant Growth Promotion

\section{Introduction}

The biopesticides based on bacteria belonging to the genus Bacillus sp. represent more than the $50 \%$ of the ${ }^{*}$ Corresponding author.

How to cite this paper: Díaz-García, A., García-Riaño, J. and Zapata-Narvaez, J. (2015) Improvement of Sporulation Conditions of a New Strain of Bacillus amyloliquefaciens in Liquid Fermentation. Advances in Bioscience and Biotechnology, 6, 302-310. http://dx.doi.org/10.4236/abb.2015.64029 
market in the world [1]. Among these, there is great interest in the development of bioproducts based on Bacillus amyloliquefaciens because these bacteria produce lipopeptides with antifungal properties, have a high rate of growth, and are "generally regarded as a safe" species according to the Food and Drug Administration of the United States and have the ability to generate structures called spores that conferred resistance to environmental and production process conditions [2] [3].

On the other hand, Colombia is one of the world's largest producers of Cape gooseberry (15,839 tons in 2006); the production of this exotic fruit is mainly located in the regions of Boyacá, Antioquia, and Cundinamarca, with 93.8\% of the total production [4]. However, in recent years, the losses due to vascular wilt caused by pathogenic fungus Fusarium oxysporum increase to 35\% in the acreage area with a decrease of $24.1 \%$ in Cape gooseberry production [4] [5]. Additionally, at the present day, chemical or biological products for the effective control of this pathogen do not exist.

To find an efficient and environmentally sustainable solution to this problem, in the Biological Control Laboratory of Corpoica, the isolation and identification of native strains of rhizobacteria have taken place, and using in vitro and in vivo bioassays, a promising microorganism identified as B. amyloliquefaciens strain Bs006 was selected because of its plant growth-promoting capacity and biocontrol activity that allows the reduction of F. oxysporum incidence to $58 \%$ in a commercial material of Cape gooseberry under greenhouse conditions [6].

In a first stage, an economic liquid culture media (coded as J) was standardized [7]; with that, a final concentration of $2.98 \times 10^{9}$ cells $/ \mathrm{ml}$ and $9.60 \times 10^{8}$ spores $/ \mathrm{ml}$ was obtained, equivalent to efficiency sporulation of $35.57 \%$ after $66 \mathrm{~h}$ of fermentation; however, this result is not suitable for scale-up processes. Therefore, to improve the profitability of liquid fermentation, facilitate the formulation process, and increase the storage stability of a bioproduct based on these bacteria, the main objective of the present work was to modify some nutritional and physicochemical factors to increase the production of spores of B. amyloliquefaciens Bs006 in liquid fermentation by applying tools of biochemical engineering and experimental design.

\section{Materials and Methods}

\subsection{Microorganisms}

B. amyloliquefaciens strain Bs006 was obtained from the Germplasm Bank of Microorganisms of Corpoica and was maintained in Luria Bertani agar (LB) slants at $4^{\circ} \mathrm{C}$.

\subsection{Growth Kinetics in Liquid Fermentation}

For inoculum preparation, bacteria grown on LB agar was recovered superficially and suspended in $100 \mathrm{ml}$ of previously standardized liquid medium "J" and the initial cell concentration was adjusted to $1.0 \times 10^{7} \mathrm{cells} / \mathrm{ml}$.

The fermentation was carried out in $500 \mathrm{ml}$ Erlenmeyer flask, incubated in a shaker New Brunswick ${ }^{\circledR}$ Innova 40 , at $28^{\circ} \mathrm{C}$ and $120 \mathrm{rpm}$ for 48 hours. Cells and spore concentrations were determined using Neubauer chamber count (BOECO, Germany). Readings were registered as cells $/ \mathrm{ml}$ and spores $/ \mathrm{ml}$. For the determination of substrate consumption, $2 \mathrm{ml}$ of fermentation broth was centrifuged at $4000 \mathrm{rpm}$ for 20 minutes and $4^{\circ} \mathrm{C}$ using a centrifuge Sorvall ${ }^{\circledR}$ Biofuge Stratos model D-37520. The supernatant was used in acid hydrolysis of the carbon source according to the methodology described by Godoy [8]. Subsequently, the colorimetric technique of 3,5 dinitrosalicylic acid was applied to determine the reducing sugars [9]. All procedures were conducted in triplicate.

For the determination of dry biomass, samples of $50 \mathrm{ml}$ of fermentation broth were centrifuged at $4000 \mathrm{rpm}$ for 20 minutes and $4^{\circ} \mathrm{C}$, the supernatant was discarded, and the wet biomass was weighed. Subsequently, the moisture of $0.5 \mathrm{~g}$ of wet pellet was determined using a moisture analyzer Radwag ${ }^{\circledR}$ model Max 50/1.

The sporulation efficiency was defined as follows:

$$
\% \text { sporulation }=\frac{(\text { final spores }- \text { initial spores })}{(\text { final cells }- \text { initial cells })+(\text { final spores }- \text { initial spores })} \times 100
$$

Additionally, the yield of substrate in biomass $\left(\mathrm{Y}_{\mathrm{x} / \mathrm{s}}\right)$, defined as the amount of biomass ( $\mathrm{g}$ ) generated by substrate consumed $(\mathrm{g})$, and the productivity $\left(\mathrm{P}_{\mathrm{x}}\right)$, defined as the biomass concentration $(\mathrm{g} / \mathrm{L})$ generated in a specific period, were determined for each trial. 


\subsection{Sporulation Induction of B. amyloliquefaciens Bs006 Using Individual Factors}

A full randomized experimental design with four factors for sporulation induction was applied; temperature $\left(\mathrm{T}^{\circ}\right)$, iron nitrate $(\mathrm{N})$, hydrogen peroxide (HO), and a mixture of salts in solution (S) were assayed. The methodology as described previously was followed; the application of each factor was carried out 24 hours after inoculation, except for the factor mixture of salts, which was added at the start in the culture media. The response variables described previously were evaluated.

The nonhierarchical pairwise comparison technique was applied to compare treatments [10], based on the following response variables: efficiency of sporulation, final spore concentration, $\mathrm{Y}_{\mathrm{x} / \mathrm{s}}$, and $\mathrm{P}_{\mathrm{x}}$. The selected culture media modified was coded as the "JM" culture media.

Afterward, the sporulation factors selected in the previous stage were combined with two initial concentrations of inoculum $\left(1 \times 10^{7}\right.$ cells $/ \mathrm{ml}$ and $1 \times 10^{8}$ cells $\left./ \mathrm{ml}\right)$ (Table 1$)$.

\subsection{Greenhouse Assay}

Cape gooseberry seeds were immersed in water at $48^{\circ} \mathrm{C}$ for 2 hours to break dormancy; later, the seeds were disinfected by washing in sodium hypochlorite (1\%) for one minute, followed by two washes with distilled water [6].

The treatments evaluated were as follows: absolute control (sterile distilled water with two applications of chemical fertilization), fermentation broth from culture media J, and fermentation broth from modified culture media JM (biomass plus supernatant in both cases).

The experimental unit consisted of a plastic tray with 50 alveoli (one seed was planted for each socket) containing soil and rice husk (2:1). The sampling unit was the seed or seedling per alveoli. The experimental design was a randomized complete block in triplicate, placed in a greenhouse.

According to the standardized methodology [6], 150 seeds for each treatment were immersed in your corresponding solution for 10 minutes, and every 15 days, $5 \mathrm{ml}$ of each fermentation broth adjusted at a concentration of $1 \times 10^{9}$ (cells + spores) $/ \mathrm{ml}$ was applied as reinforcement. Destructive sampling was conducted at 42, 51, 58, 65 , and 70 days after planting for measurement of plant growth response variables.

The stem length of each seedling was measured, and the reading was reported in millimeters.

The root and leaves of the seedling were separated from the stem, washed with water until completely clean, weighed on an analytical balance $\operatorname{Kern}^{\circledR}$ model $440.35 \mathrm{~N}$, and led independently to a drying oven at $70^{\circ} \mathrm{C}$ until constant weight. The reading was recorded in grams.

The foliar area analysis was performed using a leaf area meter CID Bio-Science ${ }^{\circledR}$.

\subsection{Statistical Analysis}

The cells and spore concentration values were transformed using a logarithmic function. All response variables were analyzed in triplicate; the ANOVA and least significant difference tests $(\mathrm{P}<0.05)$ were performed using the statistical program Statistix ${ }^{\circledR}$ v.8.

To calculate the benefit-cost for treatment, the selling price of a commercial product based on Bacillus subtilis (Agra Quest, Inc., EEUU) was used as reference. The benefit was expressed as the volume of units of final product $\left(\mathrm{U}_{\mathrm{V}}\right)$ per batch by sale price, and the final cost of product $\left(\mathrm{P}_{\mathrm{F}}\right)$ was based on a direct and indirect cost

Table 1. Experimental matrix for sporulation induction of B. amyloliquefaciens Bs006 using combination of factors.

\begin{tabular}{|c|c|c|c|c|c|}
\hline \multirow{2}{*}{ Treatment } & \multicolumn{5}{|c|}{ Factors } \\
\hline & C1 & C2 & $\mathbf{T}$ & $\mathbf{S}$ & $\mathbf{N}$ \\
\hline 1 & $\mathrm{x}$ & & $\mathrm{x}$ & $\mathrm{x}$ & \\
\hline 2 & $\mathrm{X}$ & & $\mathrm{x}$ & & $\mathrm{x}$ \\
\hline 3 & & $x$ & $\mathrm{X}$ & $\mathrm{X}$ & \\
\hline 4 & & $\mathrm{X}$ & $\mathrm{x}$ & & $\mathrm{x}$ \\
\hline 5 & & $\mathrm{x}$ & & $\mathrm{X}$ & \\
\hline
\end{tabular}

C1: initial concentration $1 \times 10^{7}$ cells/ml; C2: initial concentration $1 \times 10^{8}$ cells $/ \mathrm{ml}$, T: temperature, S: mixture of salts, N: iron nitrate. 
analysis, including the raw material. The following equation was used:

$$
\frac{B}{C}=\frac{U_{v} \times 47.00}{P_{f}}
$$

\section{Results and Discussion}

\subsection{Kinetics of Growth and Sporulation of B. amyloliquefaciens Bs006 in Culture Medium "J"}

After 66 hours of fermentation, a concentration of $1.61 \times 10^{9} \mathrm{cells} / \mathrm{ml}$ at the end of stationary phase was obtained. On the other hand, the substrate consumption reaches $50 \%$ at the end of 24 hours and $86 \%$ at the end of fermentation. The final yield was $1.68 \mathrm{~g} / \mathrm{g}$ with a productivity of $0.05 \mathrm{~g} / \mathrm{L} \cdot \mathrm{h}$.

Furthermore, when the stationary phase was reached, the spore concentration was kept constant; thus, fermentation conditions possibly favored the production of secondary metabolites minimizing the sporulation process. The highest concentration of spores was $9.60 \times 10^{8}$ spores $/ \mathrm{ml}$ at 66 hours, equivalent to sporulation efficiency of $35.57 \%$. The $\mathrm{pH}$ level remained at 7 to 8 , favorable to the production of antifungal metabolites and spores [11].

\subsection{Sporulation Induction with Individual Factors}

The treatments with addition of mix salts or iron nitrate showed the best performance in terms of final spore concentration (Figure 1) and sporulation efficiency (Table 2). Specifically, the fermentation with salt solution

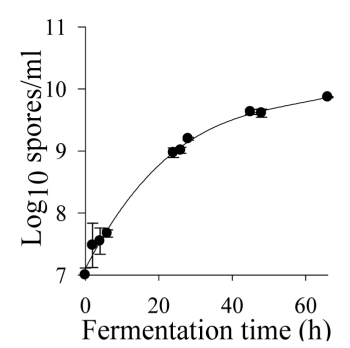

(a)

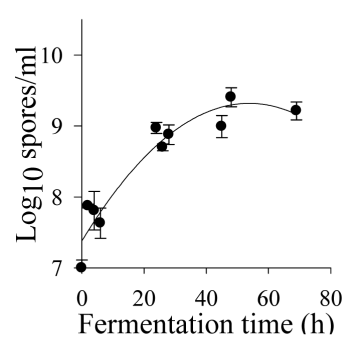

(c)

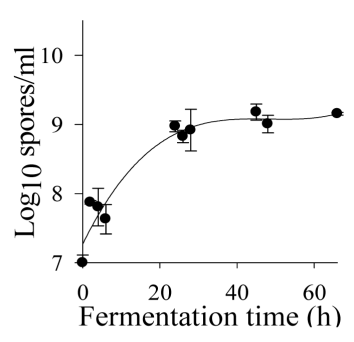

(b)

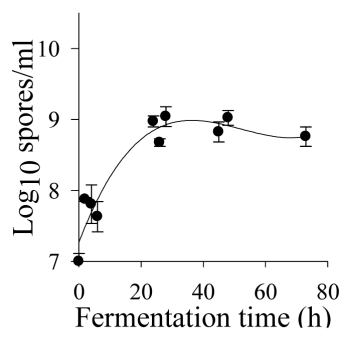

(d)

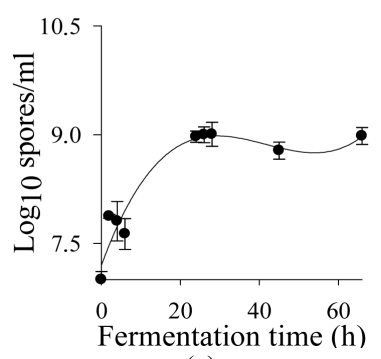

(e)

Figure 1. Growth kinetics of B. amyloliquefaciens Bs006 with different sporulation inducers. (a) Mixture of salts; (b) temperature; (c) iron nitrate; (d) hydrogen peroxide; and (e) culture media "J" (control). 
Table 2. Response variables of B. amyloliquefaciens strain Bs006 in liquid fermentation applying sporulation induction with individual factors.

\begin{tabular}{cccc}
\hline Factor & FOT (h) & Log spores/ml & SE (\%) \\
\hline T & 66 & $9.18^{\mathrm{c}}$ & $36.3^{\mathrm{c}}$ \\
$\mathbf{N}$ & 69 & $9.40^{\mathrm{b}}$ & $67.5^{\mathrm{b}}$ \\
S & 66 & $9.87^{\mathrm{a}}$ & $95.2^{\mathrm{a}}$ \\
HO & 73 & $9.02^{\mathrm{cd}}$ & $26.4^{\mathrm{d}}$ \\
Control & 66 & $8.98^{\mathrm{d}}$ & $35.6^{\mathrm{cd}}$ \\
\hline
\end{tabular}

FOT: Fermentation optimal time; SE: Sporulation efficiency; T: Temperature $\left(45^{\circ} \mathrm{C}\right)$; N: iron nitrate $(1.5 \mathrm{mM})$; S: mixture of salts $(0.315$ g/l); HO: hydrogen peroxide $(2.5 \mathrm{mM})$. Letters represent homogeneous groups obtained using LSD analysis $(\mathrm{P}<0.05)$ by each variable.

showed the higher values in spore concentration $\left(7.35 \times 10^{9}\right.$ spore/ml), sporulation efficiency (95\%), and yield of substrate in biomass and productivity and was significantly different from the control treatment $(\mathrm{P}<0.05)$.

The salts contained in the mixture have been one of the most frequently found in the culture media optimization for the production of spores [12]-[14]; because they are involved in the gene expression for dipicolinic acid synthesis, a specific component of bacterial endospores which is responsible of spore heat resistance [15]-[17].

The iron nitrate treatment showed a sporulation of $67 \%$, corresponding to a final concentration of $2.53 \times 10^{9}$ spores $/ \mathrm{ml}$, and $98 \%$ of substrate consumption at the end of fermentation. In a similar study, using a glucose-free media with the addition of iron nitrate, there was an increase in the formation of spores of B. anthracis up to $98 \%$ at the end of 36 hours with respect to the basis medium; this increase in sporulation was mainly due to the formation of iron-dependent enzymes, such as aconitase, which is a key factor in these processes [18].

On the other hand, the treatment with modified temperature was significantly higher in the final concentration of spores compared with the control $\left(1.51 \times 10^{9}\right.$ spore/ml $)$ but showed a final concentration of cells too high $\left(8.38 \times 10^{9} \mathrm{cells} / \mathrm{ml}\right)$, which led to the fall in the efficiency of sporulation.

The hydrogen peroxide treatment did not differ significantly with respect to the control, reaching low values of sporulation, and did not show any significant effect on the increase in the concentration of spores. Mishra and colleagues [19] have found that the addition of chemicals, such as hydrogen peroxide and hypochlorous acid, increased the productivity of enzymes such as $\alpha$-amylase, which suggest that B. amyloliquefaciens Bs006 drifted to metabolite production as a response to oxidative stress.

According to the experimental results, the coefficient of importance for the treatment (CIT) was calculated [10], and those treatments that showed a CIT above the culture media "J" (CIT $=0.1692)$ were selected, that is, mixture of salts $(\mathrm{CIT}=0.2736)$, iron nitrate $(\mathrm{CIT}=0.2201)$, and temperature $(\mathrm{CIT}=0.1786)$.

\subsection{Sporulation Induction with Combination of Factors}

In general, every combination of factors tested showed higher values in comparison with individual factor analysis described previously; the treatment corresponding to the mixture of salts with an initial cell concentration of $1 \times 10^{8}$ cells/ml was significantly different from the other treatments (Table 3) and reached a final spore concentration of $1.05 \times 10^{10}$ spores $/ \mathrm{ml}$, sporulation of $88.7 \%$, biomass production of $3.5 \mathrm{~g} / \mathrm{L}$, yield of biomass/substrate of $2.6 \mathrm{~g} / \mathrm{g}$, and a productivity of $0.053 \mathrm{~g} / \mathrm{l} \cdot \mathrm{h}$ that are within the higher average of all treatments. This suggests that the interaction of these factors could increase the substrate consumption and reduce the exponential phase and thus improve the sporulation process [20].

The combination of iron nitrate and temperature $\left(\mathrm{T}^{\circ}+\mathrm{N}+\mathrm{C} 1\right)$ also showed significant differences with respect to control treatment. The addition of ferric nitrate could be a stress factor for the bacteria, which leads to a more efficient process of sporulation; this might be due to the inhibition or activation of histidine phosphatases, which initiate the cascade of sporulation [18].

To select the best treatment, a normalized multi-criteria analysis was applied; the best treatment was the solution of salts in combination with an initial cell concentration of $1 \times 10^{8}$ cells $/ \mathrm{ml}$ with a CIT coefficient superior to another treatment, including control treatment, and also showed significant differences in comparison with all the treatments of individual factors (data not shown). 
Table 3. Sporulation efficiency parameters of B. amyloliquefaciens in liquid fermentation using combination of factors.

\begin{tabular}{ccc}
\hline Factor & Log spores $/ \mathbf{m l}$ & SE (\%) \\
\hline S + T + C1 & $9.55^{\mathrm{c}}$ & $84.2^{\mathrm{ab}}$ \\
$\mathbf{S}+\mathbf{T}+\mathbf{C} 2$ & $9.51^{\mathrm{cd}}$ & $90.3^{\mathrm{a}}$ \\
$\mathbf{N}+\mathbf{T}+\mathbf{C} \mathbf{1}$ & $9.64^{\mathrm{b}}$ & $73.1^{\mathrm{bc}}$ \\
$\mathbf{N}+\mathbf{T}+\mathbf{C} \mathbf{2}$ & $9.31^{\mathrm{de}}$ & $79.9^{\mathrm{c}}$ \\
$\mathbf{S}+\mathbf{C} \mathbf{2}$ & $10.02^{\mathrm{a}}$ & $88.2^{\mathrm{a}}$ \\
C2 & $9.23^{\mathrm{e}}$ & $69.6^{\mathrm{d}}$ \\
Control & $8.96^{\mathrm{e}}$ & $35.6^{\mathrm{e}}$ \\
\hline
\end{tabular}

Fermentation time: 66 hours. SE: Sporulation efficiency; T: Temperature; N: iron nitrate; S: mixture of salts; C1: initial concentration $1 \times 10^{7}$ cells/ml; C2: initial concentration $1 \times 10^{8}$ cells $/ \mathrm{ml}$. Letters represent homogeneous groups obtained using LSD analysis $(\mathrm{P}<0.05)$ by each parameter.

\subsection{Validation of the Best Treatment in Liquid Fermentation}

For the kinetics of growth of B. amyloliquefaciens Bs006 with the selected treatment (Figure 2), it was clear that fermentation conditions and the addition of inductor (mixture of salts) improved the efficiency of sporulation of B. amyloliquefaciens Bs006, reaching a final concentration of $1.05 \times 10^{10} \mathrm{spores} / \mathrm{ml}$ and corresponding to a biomass of $3.5 \mathrm{~g} / \mathrm{l}$ and a sporulation efficiency of $88.7 \%$ at 66 hours, which was significantly different from the control treatment $(\mathrm{P}<0.05)$. The final spore concentration obtained was higher than those reported by many authors; for example, Rao and colleagues [14] had a final concentration of $5.93 \times 10^{8} \mathrm{spores} / \mathrm{ml}$ in the optimization of a culture medium for the production of spores of B. amyloliquefaciens B128, whereas Warriner and Walter [21] obtained a concentration of $3.0 \times 10^{9} \mathrm{spores} / \mathrm{ml}$ with the use of simple carbohydrates in the production of spores of $B$. subtilis. With respect to $\mathrm{pH}$, a final value of 8.06 was obtained because after the depletion of the carbon source (46 hours), the medium began to alkalize, probably because of the reuptake of organic acids and deamination of peptones [21].

\subsection{Plant Growth Promotion of B. amyloliquefaciens Bs006 in Cape Gooseberry Seedlings}

In relation to the germination of Cape gooseberry seeds, at the end of 21 days after sowing (das), there were no significant differences between treatments, including the absolute control treatment, according to the LSD media comparison analysis $(\mathrm{P}<0.05)$ (data not shown).

From 42 das, significant differences between treatments with fermentation broth "J" and “JM," compared with the absolute control, were observed (data not shown); at the end of bioassay (70 das), significant differences $(\mathrm{P}<0.05)$ in six of the seven plant growth-promoting parameters evaluated were observed (Table 4).

In quantitative terms, for the treatment with fermentation broth "JM," the increment was in an order of magnitude of 100 for fresh weight; 100 and 40 for total dry weight and leaf area, respectively; and 5 for shoot length and root length. These results are very promising and demonstrate the ability of the native strain of B. amyloliquefaciens Bs006 for plant growth stimulation.

Additionally, for dry root biomass, significant differences between treatments with fermentation broth "J" and "JM" were presented; hence, the addition of inducer of sporulation did not negatively affect the development and growth of the seedlings but is capable of stimulating the growth radical and the apical elongation simultaneously, which demonstrates that $B$. amyloliquefaciens Bs006 improve the nutrient absorption, possibly by the production of plant hormones that stimulate the development of the roots and lead to a better uptake of water and nutrients [22].

On the other hand, the growth stimulation could be due to the production of indols (including indole acetic acid), some extracellular proteins, and surfactin [23]-[25]. Therefore, the colonization of root surface and effective maintenance of an optimum microbial concentration is a key factor to initiate positive interactions between host plants and plant growth-promoting rhizobacteria [26].

\subsection{Benefit-Cost Analysis}

For modified culture medium "JM" the optimization and reduction of the concentration of components from the 


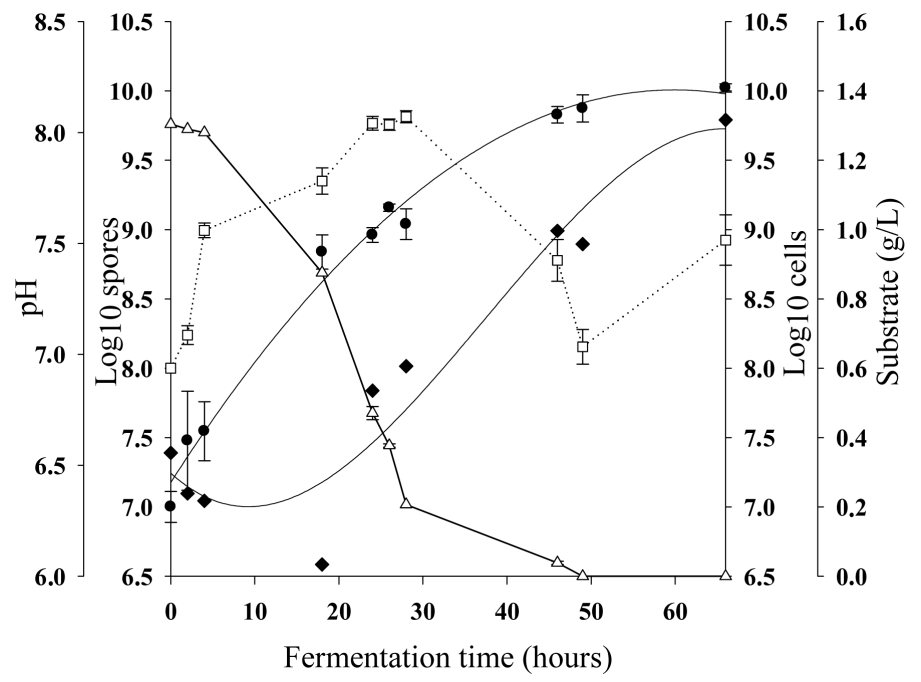

Figure 2. Kinetics of growth cell (- $\square-)$, sporulation (-๑-), pH (- -), and substrate consumption (- $\Delta-)$ of B. amyloliquefaciens Bs006 with selected treatment in liquid fermentation (mixture of salts + initial concentration $1 \times 10^{8}$ cells $/ \mathrm{ml}$ ).

Table 4. Plant growth promotion parameters in Cape gooseberry with application of different fermentation broths of $B$. amyloliquefaciens.

\begin{tabular}{cccc}
\hline Factor & Absolute control & Broth J & Broth JM \\
\hline Fresh weight $(\mathbf{g})$ & $0.018 \pm 0.006$ & $1.545 \pm 0.010^{*}$ & $1.580 \pm 0.190^{*}$ \\
Dry weight $(\mathbf{g})$ & $0.0069 \pm 0.0020$ & $0.2110 \pm 0.0700^{*}$ & $0.3532 \pm 0.0200^{*}$ \\
Foliar dry weight (g) & $0.005 \pm 0.001$ & $0.190 \pm 0.050$ & $0.271 \pm 0.100^{*}$ \\
Root dry weight (g) & $0.0016 \pm 0.0006$ & $0.0213 \pm 0.0100^{*}$ & $0.0824 \pm 0.0080^{*}$ \\
Shoot length $(\mathbf{m m})$ & $11.73 \pm 0.06$ & $59.53 \pm 12.85^{*}$ & $59.53 \pm 3.53^{*}$ \\
Root length $(\mathbf{m m})$ & $76.60 \pm 7.31$ & $194.60 \pm 33.67^{*}$ & $218.13 \pm 27.27^{*}$ \\
Leaf area $\left(\mathbf{m m}^{\mathbf{2}}\right)$ & $85.55 \pm 3.73$ & $3730.00 \pm 975.38^{*}$ & $2981.00 \pm 641.10^{*}$
\end{tabular}

The asterisk $\left({ }^{*}\right)$ represent significant differences versus control treatment, using LSD analysis $(\mathrm{P}<0.05)$ by each parameter.

conventional medium "J" had a positive impact on production costs; however, the addition of a mixture of salts represents simultaneously an increase of approximately $0.17 \mathrm{U} \$ /$ liter. Additionally, the fermentation time was increased from 48 to 66 hours, which also had an impact on the production costs related to labor, equipment, facilities, consumables, materials, and supplies (data not shown).

However, according to preliminary economic analysis, the profit obtained with liquid culture "JM" was superior to that obtained with conventional liquid culture "J" (483.29 U\$/L vs. 96.66 U\$/L, respectively). This represents a ratio of benefit-cost of the liquid culture "JM" 2.65 times higher compared with the liquid culture "J"; therefore, the mass production of B. amyloliquefaciens Bs006 in modified liquid culture media generates five-fold finished products compared with the conventional basis.

\section{Conclusion}

A modified culture media was designed for the production of spores of B. amyloliquefaciens Bs006, which, together with a modification in inoculum concentration, yields an efficiency sporulation of $88.7 \%$ with a final spore concentration of $1.02 \times 10^{10}$ spores/ml, representing an increase of $53 \%$ in the production of spores with respect to the conventional baseline; this ensures a more homogeneous biomass and increased efficiency in the fermentation process. Additionally, the fermentation broth "JM" further increased by $45 \%$ in the root biomass of Cape gooseberry seedlings and did not negatively affect other evaluated growth-promoting variables. This culture medium (coded as "JM") is a suitable alternative for the mass production of biomass of B. amyloliquefa- 
ciens Bs006.

\section{Acknowledgements}

The authors would like thank to the Ministry of Agriculture and Rural Development for the financial support to this project.

\section{References}

[1] Yanéz-Mendizábal, V., Viñas, I., Usall, J., Torres, R., Solsona, C. and Teixidó, N. (2012) Production of the Postharvest Biocontrol Agent Bacillus subtilis CPA-8 Using Low Cost Commercial Products and By-Products. Biological Control, 60, 280-289. http://dx.doi.org/10.1016/j.biocontrol.2011.12.001

[2] Schallmey, M., Singh, A. and Ward, O. (2004) Developments in the Use of Bacillus Species for Industrial Production. Canadian Journal of Microbiology, 50, 1-17. http://dx.doi.org/10.1139/w03-076

[3] Ongena, M. and Jacques, P. (2008) Bacillus Lipopeptides: Versatile Weapons for Plant Disease Biocontrol. Trends in Microbiology, 16, 115-125. http://dx.doi.org/10.1016/j.tim.2007.12.009

[4] (2010) Ministerio de Agricultura y Desarrollo Rural: Anuario estadístico de frutas y hortalizas 2006-2010 y sus calendarios de siembras y cosechas.Dirección de Política sectorial - Grupo Sistemas de Información, Bogotá, D.C, 140.

[5] (2009) Ministerio de Agricultura y Desarrollo Rural: Agenda prospectiva de investigación y desarrollo tecnológico para la cadena productiva de la uchuva en fresco para exportación en Colombia, Giro Editores Ldta. Bogotá, D.C, 2935

[6] Zapata, J. and Díaz, A. (2012) Evaluaciones en invernadero y selección de prototipos a base de rizobacterias. En: Estrategias de control biológico de F. oxysporum en el cultivo de uchuva (Physalis peruviana L.). Corpoica Bogotá, 62-70.

[7] Díaz, A., Mejía, C., Cruz, L. and Sáenz, J. (2012) Producción masiva de rizobacterias. En: Estrategias de control biológico de F. oxysporum en el cultivo de uchuva (Physalis peruviana L.). Corpoica Bogotá, 32-44

[8] Godoy, R. (2002) Método DNS para la determinación de azúcares reductores totales en melaza, sustrato de fermentación y vinos. En: Manual de métodos analíticos. Departamento de Ingeniería Química. Universidad Nacional.

[9] Miller, G. (1959) Use of Dinitrosalicylic Acid Reagent for Determination of Reducing Sugar. Analytical Chemistry, 31, 426-428. http://dx.doi.org/10.1021/ac60147a030

[10] Dean, B. and Nishry, T. (1965) Scoring and Profitability Models for Evaluating and Selecting Engineering Products. Journal Operations Research Society of America, 13, 550-569.

[11] Moita, C., Feio, S., Nunes, L., Curto, M.-J. and Roseiro, J.-C. (2005) Optimization of Physical Factors on the Production of Active Metabolites by Bacillus subtilis 355 against Wood Surface Contaminant Fungi. International Biodeterioration \& Biodegradation, 55, 261-269. http://dx.doi.org/10.1016/j.ibiod.2005.02.003

[12] Prabakaran, G. and Balaraman, K. (2006) Development of a Cost-Effective Medium for the Large Scale Production of Bacillus thuringiensis var israelensis. Biological Control, 36, 288-292. http://dx.doi.org/10.1016/j.biocontrol.2005.09.018

[13] Prabakaran, G. and Hoti, L. (2008) Egg Yolk Enhances Early Sporulation and Toxicity of Bacillus sphaericus H5a5b for Small-Scale Production of a Mosquito Control Agent. Acta Tropica, 108, 50-53. http://dx.doi.org/10.1016/j.actatropica.2008.07.007

[14] Rao, Y., Tsay, K., Wu, W. and Tzeng, Y. (2007) Medium Optimization of Carbon and Nitrogen Sources for the Production of Spores from Bacillus amyloliquefaciens B128 Using Response Surface Methodology. Process Biochemistry, 42, 535-541. http://dx.doi.org/10.1016/j.procbio.2006.10.007

[15] Oomes, S., Jonker, M., Wittink, F., Hehenkamp, J., Breit, T. and Brul, S. (2009) The Effect of Calcium on the Transcriptome of Sporulating B. subtilis Cells. International Journal of Food Microbiology, 133, 234-242. http://dx.doi.org/10.1016/j.ijfoodmicro.2009.05.019

[16] Piggot, P. and Hilbert, D. (2004) Sporulation of Bacillus subtilis. Current Opinion in Microbiology, 7, 579-586. http://dx.doi.org/10.1016/j.mib.2004.10.001

[17] Powell, F. (1953) Isolation of Dipicolinic Acid (Pyridine-2,6-dicarboxylic acid) from Spores of Bacillus megatherium. Biochemical Journal, 54, 210-211.

[18] Purohit, M., Sassi-Gaha, S. and Richard, F. (2010) Rapid Sporulation of Bacillus anthracis in a High Iron Glucose-Free Medium. Journal of Microbiological Methods, 82, 282-287. http://dx.doi.org/10.1016/j.mimet.2010.07.004

[19] Mishra, S., Noronha, S.-B. and Suraiskumar, G.-K. (2005) Increase in Enzyme Productivity by Induced Oxidative Stress in Bacillus subtilis Cultures and Analysis of Its Mechanism Using Microarray Data. Process Biochemistry, 40, 
1863-1870. http://dx.doi.org/10.1016/j.procbio.2004.06.055

[20] Sonenshein, A. (2000) Control of Sporulation Initiation in Bacillus subtilis. Current Opinion in Microbiology, 3, 561566. http://dx.doi.org/10.1016/S1369-5274(00)00141-7

[21] Warriner, K. and Waltes, W.-M. (1999) Enhanced Sporulation in Bacillus subtilis Grown on Medium Containing Glucose and Ribose. Letters in Applied Microbiology, 29, 97-102. http://dx.doi.org/10.1046/j.1365-2672.1999.00593.x

[22] Egamberdiyeva, D. and Höflich, G. (2004) Effect of Plant Growth-Promoting Bacteria on Growth and Nutrient Uptake of Cotton and Pea in a Semi-Arid Region of Uzbekistan. Journal of Arid Environments, 56, 293-301. http://dx.doi.org/10.1016/S0140-1963(03)00050-8

[23] Spaepen, S., Vanderleyden, J. and Okon, Y. (2009) Plant Growth-Promoting Actions of Rhizobacteria. Advances in Botanical Research, 51, 284-310. http://dx.doi.org/10.1016/S0065-2296(09)51007-5

[24] Choudhary, D. and Johri, B. (2009) Interactions of Bacillus spp. and Plants with Special Reference to Induced Systemic Resistance (ISR). Microbiological Research, 164, 493-513. http://dx.doi.org/10.1016/j.micres.2008.08.007

[25] Buensanteai, N., Yuen, G.-Y. and Prathuangwong, S. (2008) The Biocontrol Bacterium Bacillus amyloliquefaciens KPS46 Produces Auxin, Surfactin and Extracellular Proteins for Enhanced Growth of Soybean Plant. Thai Journal of Agricultural Science, 41, 101-116.

[26] Liu, J., He, D., Li, X.-Z., Gao, S., Wu, H., Liu, W., Gao, X. and Zhou, T. (2010) $\gamma$-Polyglutamic Acid ( $\gamma$-PGA) Produced by Bacillus amyloliquefaciens C06 Promoting Its Colonization on Fruit Surface. International Journal of Food Microbiology, 142, 190-197. http://dx.doi.org/10.1016/j.ijfoodmicro.2010.06.023 